\title{
Author Index Volume 21 (2001)
}

The issue number is given in front of the page numbers.

Bennett, R., see Burden, C.

$(3,4) 117-121$

Betterton, A. and A.D. Wade, Issues about access: serials information in an academic context: a case study

Blanken, R.R. and P.J. Vinken, Medical databases: Medline vs. Excerpta Medica

$(3,4) 123-130$

Braid, A., see Burden, C.

Burden, C., A. Reid, J. Sweeney, R. Bennett, A. Braid and J. Vickery, E-journals at the British Library: from selection to access

(2) $87-97$

$(3,4) 117-121$

$(3,4) 117-121$

Cawkell, T. and E. Garfield, Institute for Scientific Information

Cockerill, M., Biological and medical publishing via the Internet

Colling, A., see Lock, S.

Cooper, G., 'So where's the full text?' Electronic journal acquisition and use in the University of Oxford

(2) $79-86$

(1) $33-42$

$(3,4) 189-195$

$(3,4) 131-134$

$(3,4) 189-195$

Cornell, E., see Lock, S.

$(3,4) 135-137$

Dearnley, J. and C. McKnight, The revolution starts next week: the findings of two studies considering electronic books

Dorrington, L., S. Howard and J. Yeadon, Experiences with electronic journals at Imperial College

Dos Santos, B.L. and A.L. Wright, Internet-supported management education

(2) $65-78$

$(3,4) 139-143$

(2) $53-64$

Garfield, E., see Cawkell, T.

Geurts, P.A.Th.M., see Roosendaal, H.E.

Gilbert, G.A., Electronic journals - Policy and management at the University of Birmingham

(2) $79-86$

(1) $13-32$

$(3,4) 145-149$

Halliday, S., Electronic resources and academic library budgets: the PURCEL dimension

Hardy, R.L., C. Oppenheim and I. Rubbert, PELICAN: One step closer to the solution of the pricing problem

$(3,4) 151-156$

$(3,4) 157-164$

Howard, S., see Dorrington, L.

$(3,4) 139-143$

Johnson, G.J., Issues and policy: Electronic journals strategies at the University of York

$(3,4) 165-172$

Kidd, T., Electronic journal services at Glasgow University Library

Kühn, A. and C. Mainberger, Digital library activities in the Bibliotheksservice-Zentrum Baden-Wuerttemberg

$(3,4) 173-180$

(1) $1-7$

0167-5265/01/\$8.00 @ 2001 - IOS Press. All rights reserved 
Lewis, N., Redefining roles: developing an electronic journals collection at the University of East Anglia

Lock, S., E. Cornell and A. Colling, The acceptance of e-journals in higher education: policy $\&$ use at the University of Leicester, with reference to the CORSALL report

$(3,4) 189-195$

Mainberger, C., see Kühn, A.

Mallett, D.L. and A.M.H. Smith, The acceptance of electronic journals at Aston University

McKnight, C., see Dearnley, J.

(1) $1-7$

$(3,4) 197-204$

(2) $65-78$

Nelson, D., The uptake of electronic journals by academics in the UK, their attitudes towards them and their potential impact on scholarly communication

$(3,4) 205-214$

Oppenheim, C., see Hardy, R.L.

$(3,4) 157-164$

Rawson, S., Electronic journals at Queen's University Belfast: managing the transition from print

$(3,4) 215-221$

$(3,4) 117-121$

Reid, A., see Burden, C.

Roberts, S.A., Electronic journals in higher education: technology, decisionmaking and economics

Roosendaal, H.E., P.A.Th.M. Geurts and P.E. van der Vet, Developments in scientific communication: Considerations on the value chain

Rubbert, I., see Hardy, R.L.

$(3,4) 223-234$

(1) $13-32$

$(3,4) 157-164$

Scase, M.O. and B. Scott, Embedding resource based learning materials in psychology teaching

Scott, B., see Scase, M.O.

Smith, A.M.H., see Mallett, D.L.

Stark, I., Electronic journals at the University of Bath - A case study of the development of provision

Sweeney, J., see Burden, C.

(2) $43-52$

(2) $43-52$

$(3,4) 197-204$

$(3,4) 235-241$

$(3,4) 117-121$

Teskey, P. and E. Urquhart, The acceptance of electronic journals in UK higher education

$(3,4) 243-248$

Urquhart, E., see Teskey, P.

$(3,4) 243-248$

Van der Vet, P.E., see Roosendaal, H.E.

(1) $13-32$

Vickery, J., see Burden, C.

Vinken, P.J., see Blanken, R.R.

$(3,4) 117-121$

(2) $87-97$

Wade, A.D., see Betterton, A.

$(3,4) 123-130$

$(3,4) 249-261$

(2) $53-64$

Wright, A.L., see Dos Santos, B.L.

$(3,4) 139-143$

Zwollo, K., Digital document delivery and digital rights management

(1) 9- 11 